\title{
Using Excel's Matrix Operations to Facilitate Reciprocal Cost Allocations
}

Wallace R. Leese, California State University, Chico, USA

Tim Kizirian, California State University, Chico, USA

\begin{abstract}
The reciprocal method of service department cost allocation requires linear equations to be solved simultaneously. These computations are often so complex as to cause the abandonment of the reciprocal method in favor of the less sophisticated direct or step-down methods. Here is a short example demonstrating how Excel's sometimes unknown matrix operations can be used to greatly simplify the reciprocal allocation method. Students do not need to possess a strong background in matrix algebra to use this approach.
\end{abstract}

Keywords: Service Department Cost Allocation, Reciprocal Method, Excel Matrix Operations.

\section{INTRODUCTION}

n general, there are three methods available to allocate service department costs to production departments - the direct, the step-down, and the reciprocal method. The reciprocal method "is more accurate ...but is rarely used at this time" (Hilton et al, 2008). Both the direct and the step-down methods are mathematically simpler than the reciprocal method. The use of Excel's matrix operations can simplify the reciprocal method and thus make it a more viable allocation method.

\section{CASE FACTS}

A fictitious example, "Leese Company," is used to illustration this simplification. Leese Company has two service departments $\left(\mathrm{S}_{1}\right.$ and $\left.\mathrm{S}_{2}\right)$ and three production departments $\left(\mathrm{P}_{1}, \mathrm{P}_{2}\right.$, and $\left.\mathrm{P}_{3}\right)$. The services provided by the service departments to other departments are broken down as follows:

\begin{tabular}{|c|c|c|c|c|c|}
\hline \multirow{2}{*}{$\begin{array}{c}\text { Service } \\
\text { Provider }\end{array}$} & \multicolumn{5}{|c|}{ Service User } \\
\cline { 2 - 6 } & $\mathbf{S}_{\mathbf{1}}$ & $\mathbf{S}_{\mathbf{2}}$ & $\mathbf{P}_{\mathbf{1}}$ & $\mathbf{P}_{\mathbf{2}}$ & $\mathbf{P}_{\mathbf{3}}$ \\
\hline $\mathbf{S}_{\mathbf{1}}$ & $0 \%$ & $60 \%$ & $30 \%$ & $5 \%$ & $5 \%$ \\
\hline $\mathbf{S}_{\mathbf{2}}$ & $40 \%$ & $20 \%$ & $5 \%$ & $10 \%$ & $25 \%$ \\
\hline Pre-Allocation Costs & $\$ 48,000$ & $\$ 60,800$ & $\$ 120,000$ & $\$ 200,000$ & $\$ 250,000$ \\
\hline
\end{tabular}

Step 1: Determine the linear equations to be solved.

$\mathrm{S}_{1}=40 \%\left(\mathrm{~S}_{2}\right)+\$ 48,000$

$\mathrm{S}_{2}=60 \%\left(\mathrm{~S}_{1}\right)+20 \%\left(\mathrm{~S}_{2}\right)+\$ 60,800$

$\mathrm{P}_{1}=30 \%\left(\mathrm{~S}_{1}\right)+5 \%\left(\mathrm{~S}_{2}\right)+\$ 120,000$
$\mathrm{S}_{1}$ consumes $40 \%$ of the efforts of $\mathrm{S}_{2}$ and has pre-allocation costs assigned to it of $\$ 48,000$.

$\mathrm{S}_{2}$ has pre-allocation costs assigned to it of $\$ 60,800$ and consumes $60 \%$ of the efforts of $\mathrm{S}_{1}$ and $20 \%$ of its own efforts.

$\mathrm{P}_{1}$ has pre-allocation costs assigned to it of $\$ 120,000$ and consumes $30 \%$ of the efforts of $S_{1}$ and $5 \%$ the efforts of $S_{2}$. 
$\mathrm{P}_{2}=5 \%\left(\mathrm{~S}_{1}\right)+10 \%\left(\mathrm{~S}_{2}\right)+\$ 200,000$

$\mathrm{P}_{3}=5 \%\left(\mathrm{~S}_{1}\right)+25 \%\left(\mathrm{~S}_{2}\right)+\$ 250,000$
$\mathrm{P}_{2}$ has pre-allocation costs assigned to it of $\$ 200,000$ and consumes $5 \%$ of the efforts of $S_{1}$ and $10 \%$ the efforts of $S_{2}$.

$\mathrm{P}_{3}$ has pre-allocation costs assigned to it of $\$ 250,000$ and consumes $5 \%$ of the efforts of $S_{1}$ and $25 \%$ the efforts of $S_{2}$.

\section{Step 2: Determine the coefficients of the original matrix and the cost matrix.}

$\begin{array}{lll}\mathrm{S}_{1}=.4\left(\mathrm{~S}_{2}\right)+\$ 48,000 & \text { which equals }{ }^{1}: & \begin{array}{l}\mathrm{S}_{1}=.4\left(\mathrm{~S}_{2}\right)+(0)\left(\mathrm{P}_{1}\right)+(0)\left(\mathrm{P}_{2}\right)+ \\ (0)\left(\mathrm{P}_{3}\right)+\$ 48,000\end{array} \\ & \text { which converts to: } & \begin{array}{l}1\left(\mathrm{~S}_{1}\right)-.4\left(\mathrm{~S}_{2}\right)-(0)\left(\mathrm{P}_{1}\right)-(0)\left(\mathrm{P}_{2}\right)- \\ (0)\left(\mathrm{P}_{3}\right)=\$ 48,000\end{array} \\ & & \\ & & \\ \text { which }_{2}=.6\left(\mathrm{~S}_{1}\right)+.2\left(\mathrm{~S}_{2}\right)+\$ 60,800 & \mathrm{~S}_{2}=.6\left(\mathrm{~S}_{1}\right)+.2\left(\mathrm{~S}_{2}\right)+(0)\left(\mathrm{P}_{1}\right)+ \\ & (0)\left(\mathrm{P}_{2}\right)+(0)\left(\mathrm{P}_{3}\right)+\$ 60,800\end{array}$

\section{Step 3: Create the original matrix and the cost matrix.}

Create an input area with the following characteristics:

1. One row for each linear equation.

2. One column for each department plus an additional column for the pre-allocation costs. 
3. Each of the Excel cells consists of the appropriate coefficient for each equation and each department or the appropriate pre-allocation cost for each equation. (See below.)

The portion of the input area made up only of coefficients is referred to as the original matrix while the column consisting of the pre-allocation costs is referred to as the cost matrix.

\begin{tabular}{|c|c|c|c|c|c|c|}
\hline \multirow{2}{*}{$\begin{array}{c}\text { Linear } \\
\text { Equations }\end{array}$} & \multicolumn{5}{|c|}{ Departments } & $\begin{array}{c}\text { Pre-Allocation } \\
\text { Dollars }\end{array}$ \\
\cline { 2 - 6 } & $\mathbf{S}_{\mathbf{1}}$ & $\mathbf{S}_{\mathbf{2}}$ & $\mathbf{P}_{\mathbf{1}}$ & $\mathbf{P}_{\mathbf{2}}$ & $\mathbf{P}_{\mathbf{3}}$ & $\$ 48,000$ \\
\hline $\mathbf{S}_{\mathbf{1}}$ & 1.00 & -.40 & 0 & 0 & 0 & $\$ 60,800$ \\
\hline $\mathbf{S}_{\mathbf{2}}$ & -.60 & .80 & 0 & 0 & 0 & $\$ 120,000$ \\
\hline $\mathbf{P}_{\mathbf{1}}$ & -.30 & -.05 & 1 & 0 & 0 & $\$ 200,000$ \\
\hline $\mathbf{P}_{\mathbf{2}}$ & -.05 & -.10 & 0 & 1 & 0 & $\$ 250,000$ \\
\hline $\mathbf{P}_{\mathbf{3}}$ & -.05 & -.25 & 0 & 0 & 1 & \\
\hline
\end{tabular}

Original Matrix

Cost Matrix

Step 4: Using Excel's matrix operations create the inverse matrix of the original matrix.

Highlight an area the same size as the original matrix to house the inverse matrix. Immediately type "=minverse(" which should show up in the white cell. Move the cursor to the upper left-hand coefficient within the original matrix, left click your cursor and select the coefficients of the original matrix as the array. Do not include the cost matrix in the selection. Release the cursor and immediately type ")" to complete the minverse( ) function. Hold down the control and shift keys while depressing the enter key. The inverse matrix should appear in the highlighted area as follows.

\begin{tabular}{|c|c|c|c|c|c|}
\hline \multirow{2}{*}{$\begin{array}{c}\text { Linear } \\
\text { Equations }\end{array}$} & $\mathbf{S}_{\mathbf{1}}$ & $\mathbf{S}_{\mathbf{2}}$ & $\mathbf{P}_{\mathbf{1}}$ & $\mathbf{P}_{\mathbf{2}}$ & $\mathbf{P}_{\mathbf{3}}$ \\
\cline { 2 - 6 } & 1.43 & .71 & 0 & 0 & 0 \\
\hline $\mathbf{S}_{\mathbf{1}}$ & 1.07 & 1.79 & 0 & 0 & 0 \\
\hline $\mathbf{S}_{\mathbf{2}}$ & .48 & .30 & 1 & 0 & 0 \\
\hline $\mathbf{P}_{\mathbf{1}}$ & .18 & .21 & 0 & 1 & 0 \\
\hline $\mathbf{P}_{\mathbf{2}}$ & .34 & .48 & 0 & 0 & 1 \\
\hline $\mathbf{P}_{\mathbf{3}}$ & &
\end{tabular}

Inverse Matrix

Step 5: Using Excel's matrix operations, determine the reciprocal cost allocations.

Matrix multiplication can now be used to solve for the reciprocal cost allocations. The inverse matrix and the cost matrix are multiplied to create a solutions matrix as follows. Highlight an area the same size as the cost matrix to house the solutions matrix. Immediately type "=mmult(" which should show up in the white cell. Move the cursor to the upper left-hand coefficient within the inverse matrix, left click your cursor and select the coefficients of the inverse matrix as the first array. Release the cursor. Immediately type "," then select the cost matrix as the second array. Release the cursor. Immediately type ")" to complete the mmult( , ) function. Hold down the control and shift keys while depressing the enter key. The solutions matrix should appear in the area highlighted. Formatting can be added to both the inverse matrix and the solutions matrix to improve readability and understanding. See below.

\begin{tabular}{|c|c|l|}
\hline Departments & Post Allocation Costs & \multicolumn{1}{c|}{ Explanation } \\
\hline $\mathbf{S}_{\mathbf{1}}$ & $\$ 112,000$ & Total costs of $\mathrm{S}_{1}$ \\
\hline $\mathbf{S}_{\mathbf{2}}$ & $\$ 160,000$ & Total costs of $\mathrm{S}_{2}$ \\
\hline $\mathbf{P}_{\mathbf{1}}$ & $\$ 161,000$ & Post allocation costs of $\mathrm{P}_{1}$ \\
\hline $\mathbf{P}_{\mathbf{2}}$ & $\$ 221,000$ & Post allocation costs of $\mathrm{P}_{2}$ \\
\hline $\mathbf{P}_{\mathbf{3}}$ & $\$ 295,000$ & Post allocation costs of $\mathrm{P}_{3}$ \\
\hline \multicolumn{2}{|c|}{$\begin{array}{c}\text { Solutions } \\
\text { Matrix }\end{array}$}
\end{tabular}


Once the solution matrix is developed, any changes to the original matrix or the cost matrix will automatically ripple through to the solutions matrix. Thus, once established, modifications are easy to implement for continued use.

\section{CONCLUSION}

As competition encourages managers to become more concerned with accurate service department cost allocations, the use of the reciprocal service department cost allocation method should increase --provided its implementation is not overly complex. However, implementation is viewed as complex and thus this method is rarely used in practice today. Simplification should lead to more use. As shown in this paper, Excel's matrix operations can be used to simplify the reciprocal cost allocation process. Reduced complexity, resulting in more use, should enable accounting practitioners to better satisfy management's desire for more accurate cost allocations. Detailed procedures were presented illustrating the use of Excel's matrix functions to solve a fictitious reciprocal service department cost allocation problem. As practitioners become more aware of the advantages associated with using Excel's matrix functions as part of the reciprocal method, usage of this preferred allocation method should increase and more accurate cost allocations should result.

\section{AUTHOR INFORMATION}

Wallace R. Leese earned a BBA degree (Accounting) from Niagara University (1969), a MSA degree (Accounting) (1970) and a Ph.D. (Accounting) (1978) from Arizona State University. He is presently a Professor of Accounting at California State University, Chico. His teaching interests include principles, managerial, intermediate, cost, and advanced cost. He is a CMA. Professor Leese has served CSUC as Chairman of the Department of Accounting \& Management Information Systems, as Director of Graduate Business Programs, and as Associate Dean of the College of Business. Before entering academia, he worked as an auditor for Haskins \& Sells.

Tim Kizirian earned a BA degree (Finance) from Sonoma State University, an MBA (Accounting) from Cal Poly, San Luis Obispo, and a Ph.D. in accounting (Auditing) from the University of Arizona in 2001. He presently teaches at California State University, Chico in the areas of auditing and financial accounting. Before entering academia, he worked at Ernst \& Young, in their financial statement and information technology audit divisions.

\section{END NOTES}

Note that all service and production departments are included in the linear equations regardless of whether they perform services for other departments. This approach helps facilitate the determination of the original matrix coefficients.

\section{REFERENCES}

1. Blocher, E., David, S., Gary, C., Kung, C. (2008). Cost Management, A Strategic Emphasis. $4^{\text {th }}$ ed. The McGraw-Hill Companies. 454-465.

2. Hilton, R., Mayer, W., Selto, F. (2008). Cost Management For Strategic Business Decisions. The McGrawHill Companies. 370-397.

3. Horngren, C. T., Datar, S. M., Foster, G., Rajan, M., Ittner, C. Cost Accounting, A Managerial Emphasis. $13^{\text {th }}$ ed. Pearson Prentice-Hall. 546-553.

4. Kinney, M. R., Prather-Kinsey, J., Railborn, C. (2006). Cost Accounting, Foundations and Evolutions. $6^{\text {th }}$ ed. Thompson South-Western. 522-529.

5. Shank, J. (1972). Matrix Methods In Accounting. Addison-Wesley Publishing Company. 